\title{
Invasive flora in the ecosystems of the Greater Caucasus (Azerbaijan part)
}

\section{Rena T. Abdiyeva \\ Institute of Botany, Azerbaijan National Academy of Sciences, Badamdar 40, Baku, AZ1004, Azerbaijan}

Abstract: The alien flora of Azerbaijan part of the Greater Caucasus (GC) was inventoried. The study was conducted in natural (desert, psammophyte-littoral, steppe, shrub, forest, meadow), as well as anthropogenically disturbed ecosystems of Azerbaijan part of GC. Invasive species of 39 were identified (60.9\% of Azerbaijan's entire alien flora, including 64 species), of which 12 (30.7\% of the region's alien flora) are invasive. The leading families of the invasive flora of the region are Asteraceae Dumort. (11 species, 28\%), Poaceae Barnhurt (13 species; 33.3\%), Amaranthaceae Juss. (5 species, $12.8 \%$ ). Data on geographic distribution, places of concentration in the botanical-geographical and administrative districts of the region, as well as the primary habitats, taxonomic composition, life forms and status of the alien species are presented. Analysis of alien species distribution along the altitudinal belts with respect to the water regime is given. The most optimal height levels of phytoinvasions are 100-600 (700) $\mathrm{m}$ a.s.l. The factors affecting the distribution of invasive species in the region were invasion from neighboring regions and climate change. The migration routes of invasive species to the territory of the Azerbaijan part of the Greater Caucasus are considered. It has been found that the majority of invasive species are concentrated in the botanical and geographical districts bordering with Russia and Georgia, from where they penetrate into Azerbaijan. Especially ten species $(17,4 \%)$ are quickly settled and have a high reproductive potential: Acalipha australis, Amaranthus retroflexus, Ambrosia artemisiifolia, Ailanthus altissima, Erygeron canadensis, Erigeron bonariensis, Phytolacca americana, Phalacroloma annuum, Robinia pseudoacacia, Xanthium strumarium, Xanthium spinosum. Areas of concentration of invasive species and phytocenoses in which they grow are identified. Analysis of the status of invasions showed that at the moment representatives of the alien flora are only beginning to become more active in the region and the first measure to control them is periodic monitoring.

Accepted for publication: 15 May 2019

E-mail: abdiyeva.rena@mail.ru
The article also covers some historical aspects of the penetration of alien species in the Caucasus.

Key Words: alien flora, botanical-geographical districts, climate factor, migration, primary range, invasive status

\section{INTRODUCTION}

Azerbaijan is located in the south-eastern part of the European continent. More than half of the country's territory is occupied by the mountain chains of the Greater and Lesser Caucasus. The singularity of the country's relief and climatic patterns identifies the high diversity and uniqueness of the flora, which has over 4500 taxa of higher vascular plants, among which are relict, endemic, rare and endangered species [Red Book, 2013]. As a part of the Caucasus flora, the regional flora includes a broad range of geographic elements, including adventive ones, representing a group of introduced and naturalized alien species [Grossgeim, 1940].

Discussion of some historical aspects of the penetration of adventive species in the northwestern part of the Greater Caucasus, shows that the northwestern part of the Greater Caucasus is characterized by high invasiveness of the flora $-12 \%$ of the entire flora. The reasons for this lie in the natural phytocenotic background, differing in the abundance of ecotone communities. The main reason is connected with the history of peoples and ancient civilizations, concentrated in the region, the history of the anthropogenic influences. Since the ancient Stone Age, people had migrated to this part of the Caucasus, attracted by favorable natural and climatic conditions, richness and accessibility of food resources and varieties of landscapes. In the Bronze Age, long migrations of the builders of Mediterranean localities began. Spread of adventive species in this territory dates back to the end of the first millennium (Greek colonization, in the early and late Middle Ages). In the late XIX and early XX centuries the process of deliberate introduction and distribution of transformers is intensifying [Litvinskaya, Abdiyeva, 2016].

Casual alien plants are alien plants that may flourish and even reproduce occasionally outside cultivation but that eventually die out because they do not form self-replacing populations; they rely on repeated introductions 
for their persistence. Naturalized plants are those aliens that form self-replacing populations for at least 10 years without direct intervention by people (or despite human intervention) by recruitment from seeds or ramets capable of independent growth. Invasive plants are a subset of naturalized plants that produce reproductive offspring, often in large numbers, at considerable distances from parent plants, and thus have the potential to spread over a large area. Understanding of the dynamics of plant invasions requires insights on traits of the plant (elements of species invasiveness) and features of the environment. Invasions are context specific, and invasiveness only materializes when certain environmental requirements are met [Richardson, 2006; Pyšek et al., 2004b].

In recent years, expansion of alien plants has been observed all over the world, which is manifested in the clogging of local floras and vegetation, hybridization with native plants, causing the economic damage, weakening the functioning of natural floracenocomplex [Foxcroft et al., 2013; Blossey et al., 2002; Vinogradova et al., 2018]. The introduction and expansion of the ranges of invasions in local floras are the result of the increasing negative effect of anthropogenic factors exacerbated by climate change [Litvinskaya, Murtazaliev, 2015]. The importance of the solution of the issues related to alien species is evidenced by their discussion at a UN conference dedicated to the conservation of biological diversity on the problems of sustainable development [The Rio Declaration, 1992]. One of the latest documents on the issue of invasions is «Aichi Biodiversity Target 9», which states: "By 2020, invasive alien species and paths of their penetration into natural communities should be identified and be subjected to ranking on the degree of priority. The most threatening (aggressive) species must be controlled or exterminated and measures to control the pathways of distribution of such species to prevent their introduction and naturalization must be developed and adopted" [Strategic Plan for Biodiversity 2011-2020].

One of the numerous measures to control alien plants is the creation of Glo NAF database and others [The Global Naturalized Alien Flora; Pyšek, 2004a]. In connection with this, an important task of the regional and local levels is to identify the taxonomic composition of the alien flora, to study the dynamics of settlement and the bioecology of alien species, as well as to establish the degree of their aggressiveness.

In Azerbaijan, special detailed studies of phytoinvasions are just beginning: some invasive and expansive species have been studied in Absheron [Zernov, Mirzoyeva, 2014], $P h$. annum L. and A. australis L. were recorded as new alien species for Azerbaijan flora [Mehdiyeva, Geltman, 2015; Mehdiyeva et al., 2017]. A preliminary "black-list" of invasive and potentially invasive plant species has been compiled [Abdieva, 2018]. Taking into consideration the above, it was decided to make an inventory of the alien flora of the southeastern part of the GC.

\section{MATERIAL AND METHODS}

The study was conducted in 2017-2019. Azerbaijan part of the GC covers the northern and eastern territories of Azerbaijan, which borders with Russia (Dagestan) and Georgia in the north, is washed by the Caspian Sea from the east; is the largest industrial, agrarian and tourist region of the country [Mamedov et al., 2010]; The region includes eight botanical and geographical [Prilipko, 1970] and 15 administrative districts (Table 1).

The studied area has a complex geological and orographic structure, covers several climatic zones, and is characterized by pronounced vertical zonality (from -20 to $3000 \mathrm{~m}$ above sea level). In connection with this, the vegetation cover of the region represents a complex

Table 1. Botanical-geographical and administrative districts of Azerbaijan part of the GC.

\begin{tabular}{ll}
\hline \hline $\begin{array}{l}\text { Botanical-geographical districts } \\
\text { Azerbaijan part of GC }\end{array}$ & Administrative Districts \\
\hline Absheron & Absheron \\
Samur-Devechi lowlands & Siyazan, Khizi, Shabran \\
Caspian seaside lowlands & Khachmaz \\
Quba part of the Greater Caucasus & Quba, Qusar \\
Eastern (AZ) Greater Caucasus & Shamakhi, Ismayilli \\
Western (Az) Greater Caucasus & Sheki, Oguz, Qabala, Qakh, Zagatala, Balakan \\
Alazan-Ayrichay valley & Qakh \\
Qobustan & Shamakhi \\
\hline
\end{tabular}


set of water-marsh, desert, semi-desert, psammophytelittoral, upland-xerophytic, forest, steppe, meadow and rocky-scree vegetation types.

The climatic conditions of the territory are unhomogeneous, which varies from south to north and from west to east: the average annual air temperature is +12.5 $\mathrm{C}^{\circ}$, rainfall is $200 \mathrm{~mm}$ per year in the southern part (Absheron Peninsula); the average annual air temperature $+9.6 \mathrm{C}^{\circ}$, precipitation $600-1000 \mathrm{~mm}$ per year in the north-east (Quba-Qusar region); the average annual air temperature $12.5 \mathrm{C}^{\circ}$, rainfall is $600-1600 \mathrm{~mm}$ per year in the north-west (Shaki-Zagatala region) [Museibov, 1998; Mamedov et al., 2010].

Within the region under review there are cultural, wild and degrading landscapes. Such anthropogenically modified landscapes contribute to the spread of invasion. The alien species in the modified landscapes find vacant ecological niches for themselves, in which they receive an additional opportunity to fulfill their ecological requirements for the place of growth; the most aggressive species receive coenotic advantages and make adjustments to the functioning of native species and natural migration processes [Pyšek, Richardson et al., 2004b].

The study was carried out in natural (desert, psammophyte-littoral, steppe, shrub, forest, meadow), as well as anthropogenically disturbed ecosystems of the southeastern part of GC. The material for the study was literary sources, the analysis of herbarium specimens of the Herbarium of Institute of Botany (BAK), ANAS and field studies. Geographical elements was determined according to Flora of Caucasus [Flora Kavkaza, 1940-1948]. During field studies, places of growth of invasions were mapped, geobotanical features of phytocenoses with alien plants [Polevaya geobotanika, 1964] were described, life forms were established according to C. Raunkiaer [1934]. The invasive status of the species was determined in accordance with the approaches generally accepted in European invasive biology: according to which alien plants are those whose presence in an area is the result of human-mediated transport. [Richardson, Pyšek, 2006].

To clarify the degree of invasiveness, the alien plants were divided into 5 classes: Class 1 - species that do not form self-sustaining populations that, as a rule, are quickly extinguished without a constant influx of genetic material; 2 - species forming populations that have the ability to self-sustain for a certain period of time, not penetrating into natural ecosystems; 3 - species spreading in anthropogenically disturbed ecosystems (power lines, roadsides, etc.); 4 - species spreading in naturally disturbed in natural ecosystems (tree dumps, banks of mountain rivers). Class 5 includes species that can be introduced into undisturbed natural ecosystems [Yegoshin, 2016 and other]. Representatives of class 1-3 are classified as potentially invasive plants, and representatives of class $4-5$ are invasive (transformers).

\section{RESULTS AND DISCUSSION}

The alien flora of Azerbaijan part of GC currently has 39 taxa (Table 2), which constitutes $60.9 \%$ of the entire known alien flora of Azerbaijan (64 species). Out of 11 identified families, 3 families are leading - Asteraceae Dumort. (11 species, 28.2\%), Poaceae Barnhurt. (13 species; 33.3\%), Amaranthaceae Juss. (5 species, $12.8 \%)$.

Analysis of life form displayed that the prevalence of grass plants among which annual plants were represented with 25 species (64.1), perennials were 12 species $(30.8 \%)$. The participation of tree forms is insignificant - 2 species (5.1\%). According to the system of life forms of C. Raunkier [1934], the dominant were therophytes with 27 species $(69.2 \%)$, the rest were hemicryptophytes with 10 species $(25.6 \%)$, chamaephyte -with 2 species (5.1\%) and phanerophytes with 3 species $(7.7 \%)$. In relation to the water regime, the alien flora has a mesophilic character: mesophytes comprise 26 species $(66.6 \%)$, xeromeophytes 10 species $(25.6 \%)$, xeromesophytes $3(7.7 \%)$. Analysis of the primary areas showed that the basis of the invasive flora of the region is North American (12 species, 30.7\%) and South American species (7 species, 17.9\%). The distribution of the alien flora is subject to vertical zonality. It has been established that the optimal height of invasions is

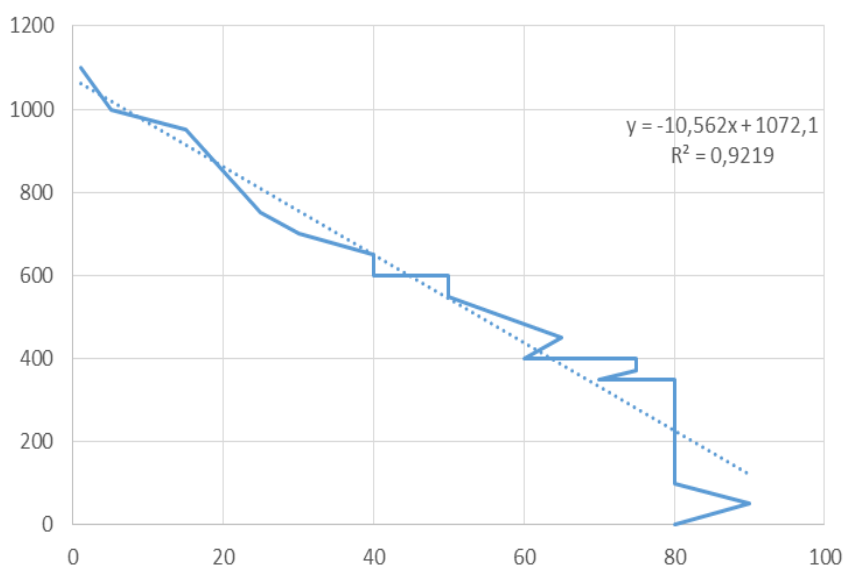

Figure 1. Distribution of alien species depending on the altitude above sea level (y-altitude a.s.l. (m), $\mathrm{x}$-occurrence of species $(\%)$. 
PLANT \& FUNGAL RESEARCH

Table 2. The most represented species in alien flora of Azerbaijan part of the GC.

\begin{tabular}{|c|c|c|c|c|c|}
\hline Family/Species & $\begin{array}{l}\text { No. of } \\
\text { bot.-geog. } \\
\text { reg. }\end{array}$ & $\begin{array}{l}\text { No. of } \\
\text { district }\end{array}$ & Primary area & Status & $\begin{array}{l}\text { Class of } \\
\text { invasive } \\
\text { activity }\end{array}$ \\
\hline $\begin{array}{l}\text { Amaranthaceae } \\
\text { Amaranthus albus L. }\end{array}$ & 4 & 4 & N America & Naturalized & 2 \\
\hline A. retroflexus $\mathrm{L}$. & 8 & 15 & N America & Invasive & 5 \\
\hline A. hybridus (L.) Thellung & 3 & 5 & N America & Naturalized & 1 \\
\hline A. blitoides $\mathrm{S}$. Watson & 1 & 1 & N America & Naturalized & 2 \\
\hline A. cruentus L. & & & S America & Naturalized & 1 \\
\hline $\begin{array}{l}\text { Asteraceae }(=\text { Compositae }) \\
\text { Ambrosia artemisiifolia } \mathrm{L} .\end{array}$ & 3 & 4 & $\mathrm{~N}$ America & Invasive & 5 \\
\hline A. trifida $\mathrm{L}$ & 1 & 1 & $\mathrm{~N}$ America & Naturalized & 2 \\
\hline Cyclachaena xanthifolia (Nutt.) Fresen & 1 & 1 & N America & Naturalized & 2 \\
\hline $\begin{array}{l}\text { Erigeron canadensis L. (=Conyza } \\
\text { canadensis) }\end{array}$ & 8 & 15 & $\mathrm{~N}$ America & Invasive & 5 \\
\hline $\begin{array}{l}\text { Erigeron bonariensis L. }(=\text { Conyza } \\
\text { bonariensis })\end{array}$ & 2 & 2 & S America & Invasive & 4 \\
\hline $\begin{array}{l}\text { Conyzanthus squamatus (Spreng.) } \\
\text { Tamamsch. (=Conyza squamata) }\end{array}$ & 2 & 2 & S America & Naturalized & 2 \\
\hline $\begin{array}{l}\text { C. graminifolius (Spreng.) Tamamsch. } \\
\text { (=Conyza graminifolium) }\end{array}$ & 2 & 2 & S \& C America & Naturalized & 2 \\
\hline Galinsoga parviflora Cav. & 4 & 10 & S America & Invasive & 4 \\
\hline Siegesbeckia orientalis L. & 2 & 3 & All America & Naturalized & 2 \\
\hline Xanthium strumarium L. & 8 & 14 & N America & Invasive & 5 \\
\hline X. spinosum $\mathrm{L}$. & 9 & 15 & N America & invasive & 5 \\
\hline Ceratophyllaceae & 1 & 1 & N America & Naturalized & 2 \\
\hline $\begin{array}{l}\text { Ceratophyllum demersum L. } \\
\text { Euphorbiaceae } \\
\text { Acalipha australis L. }\end{array}$ & 6 & 9 & E Asian & invasive & 4 \\
\hline Euphorbia humifusa Schlecht. & 3 & 5 & $\mathrm{~N}$ America & Naturalized & \\
\hline $\begin{array}{l}\text { Fabaceae (=Leguminosae) Robinia } \\
\text { pseudoacacia L. }\end{array}$ & 8 & 15 & $\mathrm{~N}$ America & invasive & 4 \\
\hline $\begin{array}{l}\text { Lythraceae } \\
\text { Ammannia aegyptiaca Willd. }\end{array}$ & 3 & 3 & not clear & Naturalized & 1 \\
\hline $\begin{array}{l}\text { Poaceae (=Gramineae } \\
\text { Bambusa arundinacea Willd. }\end{array}$ & 1 & 1 & Tropical Asian & Naturalized & 2 \\
\hline Bromus carinatus Hook.\&Arn. & 3 & 3 & S America & Naturalized & 2 \\
\hline $\begin{array}{l}\text { Bromus catharticus Vahl } \\
\text { Chloris virgata } \mathrm{Sw} .\end{array}$ & 3 & 3 & $\begin{array}{l}\text { S America } \\
\text { Large subtropical }\end{array}$ & $\begin{array}{l}\text { Naturalized } \\
\text { Naturalized }\end{array}$ & $\begin{array}{l}2 \\
2\end{array}$ \\
\hline Digitaria horizontalis Willd. & 1 & 2 & $\begin{array}{l}\text { tropical Africa \& } \\
\text { America }\end{array}$ & Naturalized & 3 \\
\hline D. violascens Link & 3 & 3 & S \& E Asian & Naturalized & 3 \\
\hline Eleusine indica (L.) Gaertn. & 1 & 1 & $\begin{array}{l}\text { Africa \& tropical } \\
\text { Asia }\end{array}$ & Naturalized & 3 \\
\hline Elymus canadensis L. & 3 & 3 & S America & Naturalized & 2 \\
\hline Paspalum dilatatum Poir. & 3 & 3 & C Asian & Naturalized & 2 \\
\hline P.thunbergii Kunth ex Steud. & 3 & 3 & C Asian & Naturalized & 2 \\
\hline Pennisetum alopecuroides (L.) Pers. & 4 & 4 & E \& S-E Asia & Naturalized & 2 \\
\hline Sorghum halepense (L.) Pers. & 4 & 4 & $\begin{array}{l}\text { Mediterranean } \\
\text { subtropical }\end{array}$ & Naturalized & 1 \\
\hline S. technicum (Koern.) Batt.et Trab. & 2 & 3 & C Asian & Naturalized & 1 \\
\hline $\begin{array}{l}\text { Phytolaccaceae } \\
\text { Phytolacca americana } \mathrm{L} \text {. }\end{array}$ & 2 & 4 & N America & Invasive & 4 \\
\hline $\begin{array}{l}\text { Pteridaceae } \\
\text { Pteris vittata } \mathrm{L} \text {. }\end{array}$ & 1 & 1 & $\begin{array}{l}\text { paleotropic } \\
\text { regions }\end{array}$ & Naturalized & 2 \\
\hline $\begin{array}{l}\text { Solanaceae } \\
\text { Datura metel L. }\end{array}$ & 3 & 3 & Indian & Naturalized & 2 \\
\hline $\begin{array}{l}\text { Simarubacea } \\
\text { Ailanthus altissima (Mill.) Swingle }\end{array}$ & 8 & 15 & E \& S-E Asia & Invasive & 5 \\
\hline $\begin{array}{l}\text { Pawlovniaceae } \\
\text { Pawlovnia tomentosa (Thunb.) Steud. }\end{array}$ & 1 & 1 & E \& S-E Asia & Naturalized & 2 \\
\hline
\end{tabular}


100-600 (700) m a.s.1. (Fig.1).

It should be noted that in the middle of the twentieth century, the highest fixed point of vertical penetration of species was 600 (700) m a.s.l. in lower mountain belt [Flora Azerbaidjana, 1952-1961]. Currently, increase in the range of invasions to $1100 \mathrm{~m}$ a.s.l. in middle mountain belt, the lower boundary of the upper mountain belt is observed which may well be connected, as we think, with global warming.

As can be seen from Fig.2, most of the alien taxa are concentrated in the botanical - geographical districts bordering with Russia and Georgia (Caspian seaside lowlands, Quba part of the Greater Caucasus, Eastern AZ Greater Caucasus, Western AZ Greater Caucasus), from where they penetrate into Azerbaijan. This is confirmed by new findings (Acalipha australis, Phalacroloma annum) growing in the above-mentioned countries and recently discovered in our areas.

Another factor that determines the distribution of

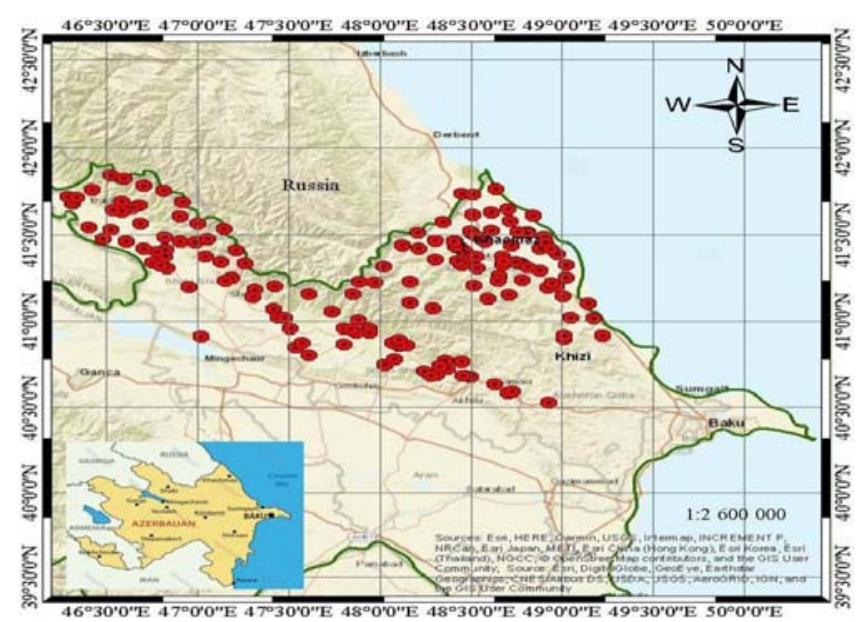

Figure 2. Localization of alien plants in Azerbaijan part of GC.

alien plants in the region is the climate. In areas with high average annual precipitation (from 600 to 1600 $\mathrm{mm}$ ), the greatest number of invasions is concentrated (Quba part of the GC - 23 taxa, Eastern GC - 27 taxa and Western GC -29 taxa) (Fig.3). Some species occur in more than one district.

In recent years, due to an increase in anthropogenic pressure (expansion of agricultural areas), as well as due to high reproductive potential and wide ecological valence, many species are beginning to actively enter natural ecosystems.

Totally $12(30.7 \%)$ species with the status "invasive" were determined, the remaining $27(69.2 \%)$ species were assessed as "naturalized" (potentially invasive). Among the naturalized plants - 17 species were classified in

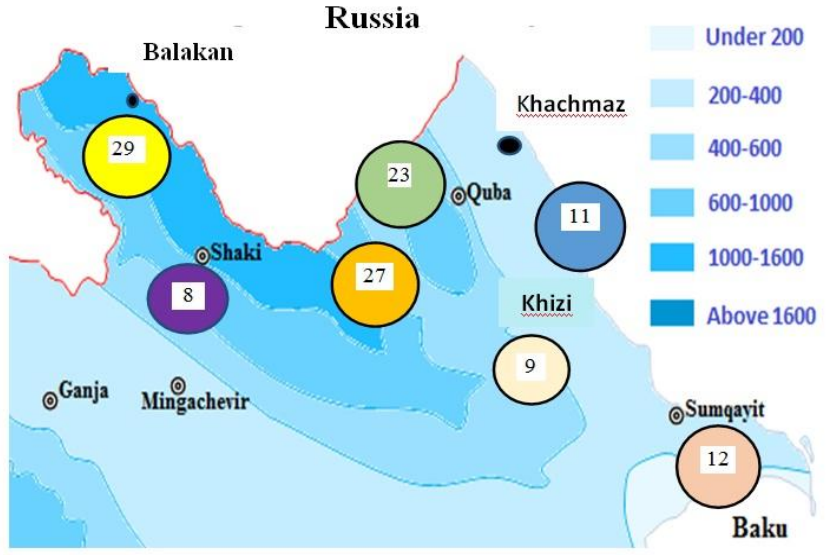

Figure 3. Quantitative distribution of phytoinvasions in climatic regions of GC.

class 2, the remaining 10 species in class 1 . Among the invasive species, 6 are assigned to the 5 th class, the remaining ones to the 6 . Our research has established that presently invasive species are introduced into the coastal (A.retroflexus, A. altissima, E. canadensis, $E$. bonariensis, $X$. strumarium, $X$. spinosum), forest (A. australis, E. canadensis, E. bonariensis, A. artemisiifolia, $A$. altissima, $P h$. americana), meadow (E. canadensis, E. bonariensis, A.artemisiifolia, A. retroflexus, $P h$. annuum) ecosystems in various areas. Of these, it is reliably known that $A$. retroflexus was introduced as a useful edible plant, since the local population still uses the representatives of the genus Amaranthus L. The species A. altissima and $R$. pseudoacacia used in the mid-twentieth century in food; they were massively planted as ornamental trees along highways. The rest are unintentionally alien. A. australis was first discovered by N.P.Mehdiyeva [2015] in Azerbaijan in Quba (GC Quba), Qakh (Western GC), Lankaran (Lankaran lowlands) and Absheron (Absheron) administrative districts. Our research (2016-2019) established new locations of $A$. australis in Goygol (Lesser Caucasus North), as well as in Siyazan, Shabran (Samur-Devechi lowland), Khachmaz (Caspian lowland), Zagatala, Balakan (GC west) administrative districts. Thus, in 5 years, this species has expanded its range by 2 times.

Stable invasive communities form $X$. spinosum and $X$. strumarium. In the vicinity of Quba region, residing along the agricultural lands, these plants begin to penetrate into the light forest and the shrub communities bordering with them. In Khachmaz district, species of the genera Xanthium L., Erygeron L., Ailanthus Desf. actively penetrate into the coastal strip of the Caspian Sea, adapt to the salinity of the sandy substrate and degrade the quality of the sandy beaches (Fig.4). 
Their tangles cover sandy ecotopes and penetrate into psammophyte-littoral and desert groups, excluding Suaeda confusa İljin, Argusia sibirica (L.) Dandy, Convolvulus persica L. and others (Fig.5). These plants also deteriorate the quality of sheep wool on weedy

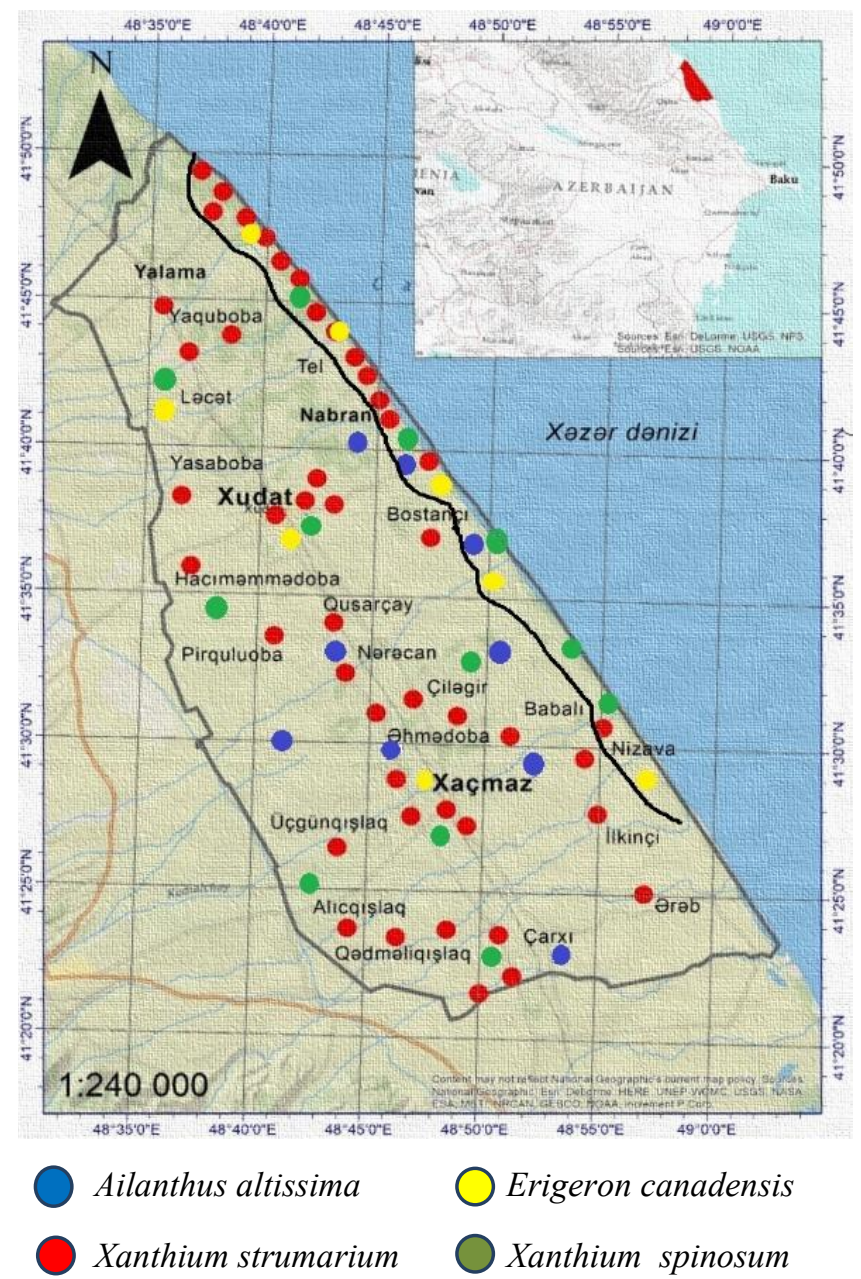

Figure 4. Localization of invasive plants in coastal ecosystems.

pastures. A. artemisiifolia, E. canadensis, P. americana with increasing frequency appear in forest ecosystems (Acer campestre + Corylus avellana ass., Carpinus betulus + Quercus iberica ass.), which penetrate from their neighboring meadow ecosystems. A. australis is also registered in the field layer of the forest (Carpinus caucasica + Fraxinus excelsior-Corylus avellana ass.), which penetrated directly from the synantrophic ecosystem.

Analysis of the alien flora showed that the total number of alien (non-native) species of the southeastern part of the GC belong to classes 1-3 of invasive valence, constitute 26 species $(66.6 \%)$ and are naturalized plants, the rest are assigned (12 species, 30.7\%)

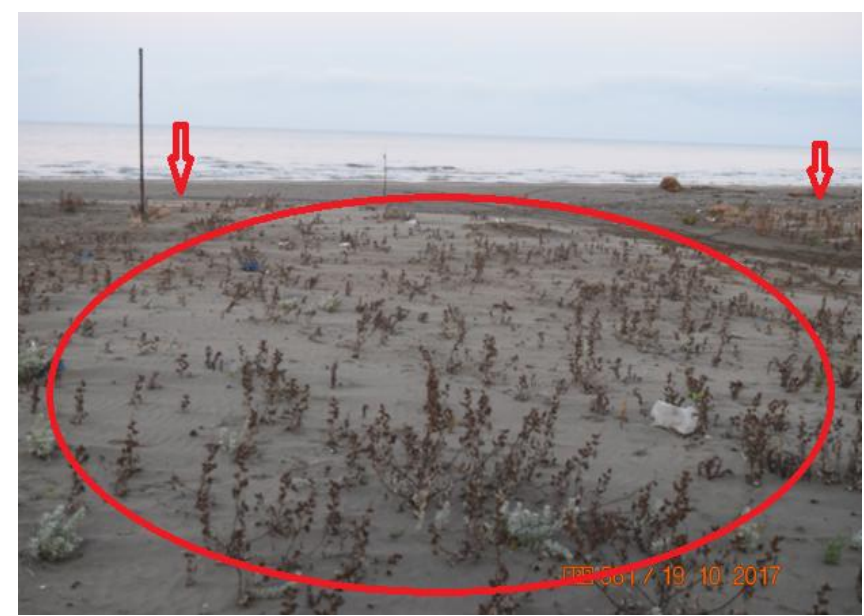

Figure 5. Xanthium strumarium on the coast

to classes 4-5 by us and are invasive - A. altissima, $A$. retroflexus, A. artemisiifolia, A. australis, E. canadensis, E. bonariensis, G. parviflora, P. annuum, P. americana, $R$. pseudoacacia, X. strumarium, X. spinozum.

\section{CONCLUSION}

At present, the growth of 39 taxa belonging to alien flora is registered in the southeastern part of the GC. Wide distribution of 13 species is noted. The main migratory bridges, which historically formed the penetration of species from Russia and Georgia, are the Caspian littoral and the piedmont utilized areas of the southern macro slope. The distribution of invasions in the region is uneven, which is due to the heterogeneity of climatic conditions. Thus, the study showed that at the moment representatives of the alien flora are only beginning to be activated in the region and the first measure on their control is periodic monitoring, studying the bioecology and vitality of invasive plants.

\section{REFERENCES}

Abdieva R.T. (2018) The list of invasive flora of Azerbaijan. Baku: Red N Line. $44 \mathrm{p}$.

Blossey B., Nuzzo V.A., Hinz H.L. and Gerber E. et al. (2002) Biological Control of Invasive Plants in the Eastern United States, USDA Forest Service Publication FHTET. 4: $413 \mathrm{p}$.

Flora Azerbaidjana. 1952-1961. Baku: AN Azerb. SSR, I-VIII (In Russian).

Foxcroft L.C., Pysek P., Richardson D.M., Genovesi P. (2013) Plant invazion in protected areas. Patterns, problems and challengers invading natur. Springer Series in Invazion Ecology, 7: $656 \mathrm{p}$.

Grossgeim A.A. (1940-1948) Flora Kavkaza. Baku: AN Azerb. SSR, 1-4 (In Russian). 
Litvinskaya S., Murtazaliev R. (2015) Vegetation diversity of the Russian part of the Caucasus in the era of climate change. In Ozturk M. et al. (eds). Climate change impacts on high-altitude ecosystems. Springer International Publishing. Switzerland, 523-544.

Litvinskaya S.A., Abdiyeva R.T. (2016) Historical aspect of the flora invazibillity of the northwestern part of the Greater Caucasus. Proceedings of ANAS, biological and medical sciences, 71(3): 17-23.

Mamedov G.Sh., Khalilov M.Y., Mamedova S.Z. (2010) Ecological Atlas. Baku, Cartographic Factory, 176 p.

Mehdiyeva N.P., Geltman D.V. (2015) Acalypha australis (Euphorbiaceae) - noviy chujerodniy vid dla flori Azerbaijana. Botanicheskiy jurnal. 100(4): 403406 (In Russian).

Mehdiyeva N.P., Dadashova A.G., Ali-zade V.M. (2017) Noviy chujerodniy dla flori Azerbaijana vid Phalacraloma annuum (Asteraceae). 112(5): 689-691 (In Russian).

Museyibov M.A. (1998) Azərbaycanın fiziki coğrafiyası. Baku: Maarif. 280 p (In Azerbaijani).

Polevaya geobotanika (1964) Ed.: E.M. Lavrenko, A.A. Korchagina. Moskva-Leninqrad: Nauka, 3: 532 pp (In Russian).

Prilipko L.İ. (1970) Rastitelniy pokrov Azerbaijana. Baku. Elm: 200 p.

Pyšek P., Richardson D.M, Rejmánek M. et alş $(2004, a)$ Alien plants in checklists and floras: towards better communication between taxonomists and ecologists, 53: 131-143.

Pyšek P., Richardson D.M., Williamson M. (2004,b) Predicting and explaining plant invasions through analysis of source area floras: some critical considerations. Divers Distrib, 10: 179-187.

Raunkiaer C. (1934) The life forms of plants and statistical plant geography. Oxford: Clarendon press: 632 p.

Red Book of the Republic of Azerbaijan (rare and endangered species of plants and fungi). (2013) Baku, $665 \mathrm{pp}$.

Richardson D.M., Pyšek P. (2006) Plant invasions: merging the concepts of species invasiveness and community invasibility. Prog Phys Geogr, 30(3): 409-431.

Rio Declaration on Environment and Development 1992, www.jus.uio.no

Strategic Plan for Biodiversity 2011-2020, Aichi Biodiversity Targets, www.cbd.int/sp/targets/rationale/ target-9/

The Global Naturalized Alien Flora (GloNAF) data- base, www.glonaf.org

Vinogradova Y. et al.(2018) Invasive alien plants of Russia: insights from regional inventories Biological Invasions, 20(8): 1931-1943.

Yegoshin A.B. (2016) Inozemniye vidi yuga Rossiyskogo prichernomorya, ikh bioklimaticheskiye I ekologicheskiye geograficheskiye trebovaniya. Vestnik RUDN, seriya ekologiya I bezopastnost jiznedeyatelnosti,1: 7-15 (in Russian).

Zernov A.S., Mirzoyeva Sh.N. (2014) Chujerodniye vidi sosudistikh rasteniy vo flore Apsheronskogo poluostrova (Azerbaijan). Moskva. Sbornik materialiv IV Mejdunarodnoy nauchno-prakticheskoy konferensii «Aktualniye problemi ekologicheskoy i ximicheskoy biologii», 23-27 pp.

\section{Böyük Qafqaz ekosistemlərində invaziv flora (Azərbaycan daxilində)}

\section{Rəna T. Abdiyeva}

AMEA Botanika Institutu, Badamdar şossesi 40, Bakl, AZ1004, Azorbaycan

Böyük Qafqazın (BQ) Azərbaycan hissəsinin invaziv florasının inventarizasiyası aparılmışdır. Tədqiqat BQin Azərbaycan hissəsinin təbii (səhra, psammofit-littoral, çöl, kol, meşə, çəmən), o cümlədən antropogen fəaliyyət nəticəsində pozulan ekosistemlərindəhəyata keçirilmişdir. Burada 39 yad mənşəli (64 növ daxil olmaqla Azərbaycanın ümumi florasının 60.9\%-i) bitki növü qeyd olunmuşdur ki, bunlardan da 12-si (regionun yad florasının 30.7\%) invaziv növlərdir. Asteraceae Dumort. (11 növ, 28\%), Poaceae Barnhurt. (13 növ; 33.3\%), Amaranthaceae Juss. (5 növ, 12.8\%) regionun invaziv florasının əsas fəsilələrini təşkil edir. Yad növlərin coğrafi paylanma, regionun botanikicoğrafi və inzibati regionlarındatoplaşma yeri, eləcə də, əsas təbii mühiti, taksonomik tərkibi, həyat formaları və statusu haqda məlumatlar verilir. Yad növlərin su rejimi ilə bağlı hündürlük qurşaqları boyunca paylanması təhlili dətəqdim edilir. Fitoinvaziyanın ən optimal hündürlük səviyyəsi dəniz səviyyəsindən 100-600 (700)m təşkil edir. Regionda invaziv növlərin paylanmasına təsir göstərən faktorlar qonşu regionlardan invaziya və iqlim dəyişikliyidir. İnvaziv növlərin BQ-1n Azərbaycan hissəsinin ərazisinə miqrasiya yolu nəzərdən keçirilmişdir. Təhlillər nəticəsində aşkar edilmişdir ki, invaziv növlərin əksəriyyəti Rusiya və Gürcüstanla həmsərhəd olan botaniki-coğrafi rayonlarda yayılmışdır, buradan isə onlar Azərbaycan ərazisinə daxil olurlar. Xüsusilə, 12 növ daha sürətlə yerli floraya daxil olur və yüksək reproduktiv potensiala ma- 
likdir: Acalipha australis, Amaranthus retroflexus, Ambrosia artemisiifolia, Ailanthus altissima, Erygeron canadensis, Erigeron bonariensis, Galinsoga parviflora, Phytolacca americana, Phalacroloma annuum, Robinia pseudoacacia, Xanthium strumarium, Xanthium spinosum. Yad növlərin toplandığ 1 ərazilər və onların yayılma ərazilərində fitosenozu müəyyən edilmişdir. İnvaziv floranın vəziyyətinin təhlili göstərir ki, hazırda yad flora növlərinin nümayəndələri regionda intensivləşməyə başlayır və onlara nəzarət olaraq ilk tədbir mütəmadi monitorinqlərin aparılmasından ibarətdir. Məqalədə yad növlərin Qafqaza daxil olmasının bəzi tarixi aspektləri də müzakirə edilir.

Açar sözlor: yad mənşali flora, botaniki-coğrafi rayon, iqlim faktoru, miqrasiya, ilkin areal, invaziv status

\section{Инвазивная флора в экосистемах Большого Кавказа (в пределах Азербайджана)}

\section{Рена Т. Абдыева}

Институт Ботаники НАНА, Бадамдар 40, Баку, АZ1004,Азербайджан

Инвентаризована заносная флора азербайджанской части Большого Кавказа (БК). Объектами исследования служила растительность естественно-природных (пустынные, псаммофитно-литоральные, степные, кустарниковые, лесные, луговые), а также антропогенно нарушенные экосистемы азербайджанской части БК. Выявлены 39 заносных видов (60.9\% от всей заносной флоры Азербайджана, включающей 64 вида), из которых 12 (30.7\%, от заносной флоры региона) являются инвазивными. Ведущими семействами инвазионной флоры региона являются Asteraceae Dumort. (11 видов, 28\%), Poaceae Barnhurt. (13 видов; 33.3\%), Amaranthaceae Juss. (5 видов, 12.8\%).Представлены данные о гео- графическом распределении, местах концентрации в ботанико-географических и административных районах региона, а также об основных местообитаниях, таксономическом составе, формах жизни и статусе чужеродных видов. Дан анализ распределения чужеродных видов по высотным поясам и отношение к водному режиму. Наиболее оптимальные высотные уровни произрастания фитоинвазий являются 100-600 (700) м над ур. моря. Выявлены факторы, влияющие на распространение инвазивных видов в регионе - инвазия из соседних регионов и климатические изменения. Рассмотрены пути миграции инвазивных видов на территорию азербайджанской части БК. Выяснено, что большинство инвазивных видов сосредоточено в ботанико-географических районах, контактирующих с Россией и Грузией, откуда они проникают в Азербайджан. Особенно быстро расселяются и имеют высокий репродуктивный потенциал 12 видов - Acalipha australis, Amaranthus retroflexus, Ambrosia artemisiifolia, Ailanthus altissima, Erygeron canadensis, Erigeron bonariensis, Galinsoga parviflora, Phytolacca americana, Phalacroloma annuum, Robinia pseudoacacia, Xanthium strumarium, Xanthium spinosum. Установлено, что наиболее уязвимыми природными экосистемами являются прибрежные и лесные. Выявлены районы концентрации инвазивных видов и фитоценозов, в которых они произрастают. Анализ статуса инвазий показал, что на данный момент представители заносной флоры только начинают активизироваться в регионе и первой мерой по их контролю является периодический мониторинг. В статье также затрагиваются некоторые исторические аспекты проникновения заносных видов на Кавказе.

Ключевые слова: заносная флора, ботаникогеографический район, климатический фактор, миграчия, первичный ареал, инвазионный статус 